$$
\begin{aligned}
& \text { Authors: L Juma } \\
& \text { and J Tsabora }
\end{aligned}
$$

\title{
THE SOUTH AFRICAN DEFENCE REVIEW (2012) AND PRIVATE MILITARY / SECURITY COMPANIES (PMSCS): HERALDING A SHIFT FROM PROHIBITION TO REGULATION?
}

\section{ISSN 1727-3781}

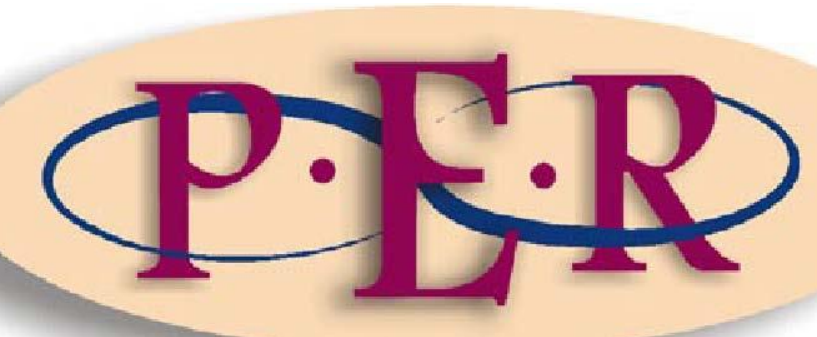

2013 VOLUME 16 No 4 


\section{THE SOUTH AFRICAN DEFENCE REVIEW (2012) AND PRIVATE MILITARY / SECURITY COMPANIES (PMSCS): HERALDING A SHIFT FROM PROHIBITION TO REGULATION?}

\section{Juma* \\ J Tsabora**}

\section{Introduction}

The arrest in February 2013 of twenty suspected Congolese rebels, allegedly training in South Africa to overthrow Kabila's government, ${ }^{1}$ carries potent symbolism of the vestigial gaps in South Africa's security infrastructure, even as it struggles to find its feet in the post-apartheid environment. That the rebels were found training deep in the heart of South Africa's Northern Province echoes the painful memory of a horrendous past, when the country played host to factions hostile to democratic African governments opposed to the apartheid regime. ${ }^{2}$ It also serves as a reminder that South Africa is yet to plug the holes in its security infrastructure, that allow its soil to be used by private military and security outfits that have their intentions set on causing havoc across the border. Considering that in the recent past there have been other incidents of similar pathology, such as the arrest of Mark Thatcher, son of the former British Prime Minister, Lady Thatcher, in South Africa for allegedly financing a coup plot in Equatorial Guinea, ${ }^{3}$ and the arrest and subsequent imprisonment of Henry Okah, the alleged mastermind of the deadly terrorist bomb attack in the Nigerian city of Abuja during the celebration of the $50^{\text {th }}$ year of

Laurence Juma. LLB (Nrb) LLM (Penn) MA (Notre Dame) LLD (UFH). Professor of Law, Rhodes University. E-Mail: I.juma@ru.ac.za.

** James Tsabora. LLB (UZ) LLM (UKZN) PhD (Rhodes). Post-doctoral research fellow, Rhodes University. E-Mail: j.tsabora@ru.ac.za.

1 See CNN 2013 edition.cnn.com; SABC 2013 www.sabc.co.za; Staff Reporter 2013 mg.co.za; BBC 2004 news.bbc.co.uk.

2 See eg Geldenhuys 1982 Politikon 16; Howe 1998 J Mod Afr Stud 307; Kagwanja 2006 JCAS 159; Hanlon 1987 Third World Quarterly 437.

3 See Tempest and Jeffrey 2004 www.guardian.co.uk; Franklin 2008 Transnat'l L \& Contemp Probs 248. 
independence, ${ }^{4}$ the conclusion that South Africa is yet to overcome its security problems may not be far-fetched.

But just as these events may be unsettling to policy makers and government officials, given the prominent role that South Africa plays in continental governance, ${ }^{5}$ they have also re-ignited debates on how the country should deal with the new face of privatisation in the security industry - the private military and security companies (PMSCs). It should be recalled that South Africa was among the first African countries to pass a law criminalising mercenary activities - the Prohibition of Mercenary Activities and Regulation of Certain Activities in of Armed Conflict Act 2006. ${ }^{6}$ The Act, which sought to replace the Regulation of Foreign Military Assistance Act of 1998 (RFMA), ${ }^{7}$ represented the government's clearest attempt to rein in privateers in the security industry who operate in conflict zones and threaten fragile African states. Propelled by political impulse rather than objective assessment, the Act merely responded to the need to curb armed activities that went against the grain of South Africa's most touted desire to be the kingpin of continental peace and security. ${ }^{8}$ Moreover, the law was based on a policy framework which did not envisage the surge on liberalisation in the security sector that we see today. It is no surprise, therefore, that the law has remained largely moribund, and questions have now arisen as to whether its framework, and indeed that of any other law of its pedigree, is suited for dealing with the challenges that the PMSC phenomenon currently poses for South Africa and the continent at large. ${ }^{9}$

We shall be arguing in this article that a weak legal framework, moulded on antimercenary ideology, is unlikely to deal with the manifold problems that arise from the operational conduct of PMSCs. A commitment by the government based on a

\footnotetext{
4 See Gruenbaum 2010 Round Table 585; BBC 2010 news.bbc.co.uk; BBC 2013 news.bbc.co.uk.

5 See Barker 2005 Int'l Affairs 1079; Jobson 2012 www.guardian.co.uk.

6 Prohibition of Mercenary Activities and Regulation of Certain Activities in of Armed Conflict Act 26 of 2006 (hereinafter Mercenary Act). The Act was signed into law by President Mbeki in 2007, but it has not come into effect because the rules for its implementation have not yet been promulgated.

7 Regulation of Foreign Military Assistance Act 15 of 1998 (RFMA).

8 See Taljaard "Private and Public Security" 83.

9 See Mesner "Working Towards Effective Legislation" 152.
} 
target policy and backed by proper legislative framework, is urgently needed. Thus far, the indicators of a robust commitment may be sparse, but glimpses show that reform is imminent. That reform, when it arrives, will most likely take a directional shift from prohibition to regulation. The most visible indicator yet is the Defence Review of $2012,{ }^{10}$ which welcomes privatisation in the security industry and, in not so many words, recognises the importance of the evolving phenomenon of PMSCs and the increasing need for a regulatory framework. In this article we attempt to unravel the extent to which the political commitment as evidenced by this policy document may influence normative change, and estimate the likelihood of a paradigm shift in objectives and priorities towards dealing with private security concerns. Our focus is not on the policy document per se, but on how its policy imperatives, galvanised by the emerging shift towards regulation rather than prohibition, may affect normative development in this area.

We begin our enquiry by feeling our way towards an understanding of what PMSCs are, and isolating the reasons why regulations and are necessary. Thereafter, we examine the general deficit in South Africa 's normative infrastructure dealing with PMSCs and point out why we believe that the Defence Review 2012 enunciates a new era in the security reform agenda. We then take a comparative survey of the current state of international law relating to PMSCs and illustrate how the emerging shift from prohibition to regulation has more than affirmed the need for legislative intervention. In this regard, we interrogate whether the evolving policy framework is now setting a new agenda for legislative action concomitant with developments at the international level. We also question whether there is justification for South Africa to remain stuck in the outdated politics of mercenarism, or remain beholden to the prohibitionist mantra of the continental bodypolitik, when the prospect of a secure South Africa rests with pragmatism and targeted reforms in its security infrastructure that go in tandem with dynamic changes at the global level. In conclusion, we suggest that more effort should be directed at designing appropriate mechanisms for dealing with PMSCs than at putting PMSCs out of business. And since the future is on the side of regulation, not prohibition, legislation that furthers

10 Department of Defence 2012 www.info.gov.za (hereinafter Defence Review). 
the policy agenda envisioned by the Defence Review may be the best tool to unlock the inhibitions of the past and to align South Africa's security aspirations with those of the rest of the world.

\section{PMSCs: What are they?}

There is consensus that PMSCs should be distinguished from mercenaries, even though their operations may occasionally overlap. ${ }^{11}$ PMSCs are essentially wellorganised and registered corporations that offer private military and general security services for hire. They are supposed to be civilian organisations although their work may be difficult to categorise. Some of them offer services that are coercive in nature, such as combat, guarding and protection, interrogation and detention. ${ }^{12}$ Whilst performing such tasks, these PMSCs are expected to follow military rules and practices, and to adopt military codes in the same manner as national armies. Whether or not they remain civilians and should be treated as such by law has been the subject of a protracted debate. ${ }^{13}$ On the other hand, there are PMSCs that offer non-coercive services, even though they operate within a military setting. Such 'noncoercive' services may include logistical support, weapons maintenance, sanitation, laundry services to missions, and the movement of military personnel. ${ }^{14}$ No matter the nature of the services PMSCs provide, war is a business opportunity for all of them. Armed conflicts, political instability and collapsed security situations in politically troubled states are, beyond any doubt, their richest source of lucre. For this reason, their involvement in a conflict situation is often viewed with suspicion, especially because their motivation may simply be to make money and support their benefactor irrespective of the morality of the cause. This apart, because of the nature of their work, PMSCs' operations are often transnational in character and beyond the scope of the regulatory systems in any one single state. For this reason PMSCs are ordinarily less constrained in taking advantage of collapsed legal, political

11 See eg Salzman 2008 NYUJ Int'l L \& Po/ 853; Juma "Mercenarism" 197; Brooks 2007 JIPO 4.

12 See Hoppe 2008 EJIL 1006.

13 See eg Davidson 2000 Pub Cont L; Schmitt 2005 Chi J Int'l L; Jackson 2007 J Nat'l Ass'n Admin L Judiciary 35.

14 See eg Defence Review para 47b. 
and security systems of the hiring state, and consequently more likely to commit serious violations and abuses in the pursuit of their objectives.

Despite their international focus, PMSCs are often registered as business entities under the domestic corporate laws of their home states. Such registration essentially grants them corporate legal personality, meaning they can sue or be sued and their activities have to be in compliance with the domestic corporate laws of their home states. Notwithstanding, states face constraints in their efforts to effectively monitor and control the extra-territorial activities of PMSCs registered under national law. These extra-territorial activities are often but not always on the basis of contracts with foreign governments, regimes and armed opposition groups for the provision of their services in return for profit. Since such contracts are ordinarily not subject to the laws of the home states of the PMSCs, it is difficult to use this domestic law to determine the legal validity of the ensuing legal contractual relationships, and the nature of services that should be performed in foreign countries. So even with the best intentions, home states may face considerable difficulty in regulating the activities of PMSCs.

PMSCs also hire out their services to non-state actors ${ }^{15}$ and weak and fragile governments in transition following periods of war or political instability. ${ }^{16}$ Regrettably, a substantial volume of PMSCs' activities is conducted through informal and discrete arrangements, facilitated by international private corporations, private military networks, arms brokers and third-party agents present in the conflict state and neighbouring states. These other 'partners' are also crucial in logistics, planning and preparation, as well as in the acquisition, transportation and deployment of materials necessary in the performance of their contractual responsibilities. In such situations there could be multiple entities and individuals with no proper chain of command involved in operations carried out by PMSCs. For this reason, accountability for human rights violations may be very difficult to enforce. ${ }^{17}$ In addition, PMSCs may pose a risk to state security when their renegade employees

15 See Abrahamsen and William 2007 Int'l Relations 237.

16 See Cilliers and Cornwell 1999 ASR 31-42.

17 See eg Amann 2005 U Pa L Rev 2085; Raghavan and White 2007 www.washingtonpost.com. 
forge links with organised crime syndicates and bands of rebel soldiers who survive on the ruthless and illegal extraction of natural resources. ${ }^{18}$ In situations of conflict these entities could contribute to the prolonging of the conflict and become a greater hindrance to peace. These problems are further aggravated by inchoate and sometimes minimal regulatory mechanisms in their home countries. ${ }^{19}$ So, while PMSCs' operatives may incur criminal and civil liability for violation of human rights and international humanitarian law on a theoretical level, in reality prosecutions are very rare.

In the light of the nature of the PMSCs profession, and because their services are discharged in particularly hostile security environments, PMSCs have to rely on former military personnel, to a significant extent, to provide their services. ${ }^{20}$ This is borne out by the number of South African PMSCs, and their counterparts abroad, that have recruited former apartheid military officers and personnel after the fall of apartheid. ${ }^{21}$ A 2005 report estimated that there were about 5,000 to 10,000 South Africans working for PMSCs in Iraq. ${ }^{22}$ Undoubtedly, therefore, South Africa has a greater interest than most other African countries, in regulating their PMSC industry. But as South Africa responds to this need, there will always be a dilemma: treating PMSCs like any other corporate entities that enjoy freedom of contract with parties of their choosing might endanger domestic, regional and continental security and damage South Africa's international relations and foreign policy. On the other hand, limiting the legal rights of PMSCs to contract should be done carefully to ensure that such restrictions comply with the country's constitutional and legal framework. ${ }^{23}$ This dilemma compels an enquiry into how South Africa should deal with the PMSC question.

18 McIntyre 2004 ASR 101.

19 See Prado 2011 BJWA 153.

20 Zarate 1998 Stan J Int'l L 76.

21 See Lock "Africa, Military Downsizing" 12.

22 See Clarno and Vally 2005 www.corpwatch.org.

23 Section 22 of the Constitution of the Republic of South Africa, 1996 provides: "Every citizen has the right to choose their trade, occupation or profession freely. The practice of a trade, occupation or profession may be regulated by law. " 


\section{South Africa's response to the PMSCs problematique}

Since the defeat of apartheid, genuine attempts have been made to reform the security sector while prioritising the protection of individual rights and freedoms, human security and the democratisation project. As far as privatisation in the security sector is concerned, the challenge was seen, initially, to be that of harnessing the wayward security apparatuses scuttled after the overthrow of the apartheid regime, so that they didn't portend harm to other African states. In the recent past, however, the concerns have escalated as the private players in the sector have metamorphosed into corporate organisations with transnational appeal. However, and as we shall demonstrate in the latter part of this article, the policies and norms put in place to deal with this challenge have remained largely reactionary and tepid. The laws that have been passed thus far have tended to focus on prohibition rather than regulation, are inflexible, and are therefore unable to accommodate change in the security sector.

Before we discuss these norms in reasonable detail it may be worthwhile to give a broader overview of the policy instruments that have responded to the defence and security needs of South Africa as it sought to consolidate its democracy and entrench its hold on continental power politics. In the period following the 1994 democratic elections the government adopted two important policy documents that defined its future security reform agenda: the 1996 White Paper on Defence ${ }^{24}$ and the 1999 White Paper on Defence Related Industries. ${ }^{25}$ These two policy instruments cover considerable ground but with minimal differences mainly dictated by their temporal contexts. Presumably, and generally speaking, the 1996 White Paper was aimed at dismantling the apartheid system, while the 1999 one was an attempt to build an authentic security infrastructure that was consistent with South Africa's emerging role as a continental leader. Given the limited space, we shall attempt to set out only some generalities in the reform trajectory expressed by these two papers that are relevant to our subject. Primarily, both instruments adopt a very

24 See White Paper on National Defence for the Republic of South Africa (1996).

25 See White Paper on South Africa Defence Related Industries (1999). 
wide interpretation of national security that includes aspirations for democratic consolidation, social justice, economic development, human rights, and even political stability. They also put great emphasis on the reform of public institutions, mainly the South African Defence Forces (SADF). They are couched in transformative lingo, but with scant details on how their objectives are to be achieved. Hidden in the details are their affirmation of the role of international law in dealing with security issues. This has had a critical importance to security reform because it indicated, from the very beginning, the willingness of the new South Africa to be bound by international treaties and Conventions. Obviously, therefore, the policy imperatives embodied in the two papers paved the way for the domestication of international standards in South Africa.

Notwithstanding the broader focus of these policies, their key objective remained "the political transition from apartheid to a democratic South Africa and the concomitant integration of diverse statutory and non-statutory armed forces into a single Defence Force." ${ }^{126}$ A key factor in this transitional agenda was thought to be the demobilization and rationalization of the defence forces. Although these processes were to be carried out in accordance with the principles of fair labour practices, transparency, equality, and with due regard to the need to retain expert personnel, they effectively reduced the number of trained white military personnel in the force. No wonder a great number of qualified white personnel were rendered jobless or voluntarily left the force. Many of such personnel later provided a pool of expert military labour that fueled the growth of the private military and security industry in South Africa. Thus, although the two policies did not mention mercenaries or private security organizations, the processes which they engendered directly resulted in the proliferation of such entities. A mercenary outfit such as the defunct Executive Outcomes that was involved in the Sierra Leone conflict was formed by ex-SADF soldiers. ${ }^{27}$ The current crop of PMSCs based in South Africa such as Bridge Resources International, Corporate Trading International, Erinys

26 See ch 1, para 6 Defence Review.

27 For detailed discussion of the origins of Executive Outcomes, see Barlow Executive Outcomes. 
International and even Falconer Systems, have equally benefitted from the downsizing of the SADF. ${ }^{28}$

Produced at the time when South Africa was asserting itself as the power broker in continental affairs, the drafters of these policy instruments must have been aware of the political aversion to mercenarism among the African states. Indeed, African states had made their position clear by adopting the 1977 Mercenary Convention. ${ }^{29}$ Although moribund in many respects, the convention represented a wide consensus on the undesirability of private military entities operating in the continent. Further, its prohibitionist approach was evident in almost all deliberations on continental security and massively influenced the tone of normative developments at the domestic level. Given the urgency with which South Africa sought to entrench itself in continental affairs, its support of the prohibitionist approach was neither interrogated nor debated at the time when it enacted its domestic laws dealing with mercenaries, such as the Regulation of Foreign Military Assistance Act and the Prohibition of Mercenary Activities and Regulation of Certain Activities in Country of Armed Conflict Act.

Clearly, contemporary developments in the global security landscape necessitate a constant review of policies and normative frameworks relating to PMSCs. Thus, domestic law and policy can have meaningful impact when aligned to evolving trends. It is for this reason that we suggest in this paper that South Africa must consider enacting law regarding security to keep up with the momentum of change. The policy instruments we mentioned earlier predate the critical developments in defence and private military security and cannot move South Africa forward as it seeks to assert its role as a major player in continental security affairs. The shift from the familiar mould of prohibition to the more progressive path of regulation that is evident in the Defence Review 2012 is thus to be welcomed. Before we examine how the policy imperatives in this new document may impact on the

28 See Kinsey Corporate Soldiers 5.

29 OAU Convention for the Elimination of Mercenaries in Africa (1972). For a discussion of the shortcomings of the Convention, see Abrahams "Contemporary Legal Environment" 81. 
evolution of norms, it might be useful to survey existing normative terrain and identify some of the shortcomings that legitimise the call for a revised approach.

\subsection{The Prohibition of Mercenary Activities and Regulation of Certain Activities in Country of Armed Conflict Act}

Currently the major domestic piece of legislation dealing with mercenaries and private security companies is the Prohibition of Mercenary Activities and Regulation of Certain Activities in Country of Armed Conflict Act (the Mercenary Act). ${ }^{30}$ The Act was signed into law by President Thabo Mbeki in November $2007 .{ }^{31}$ It embodies what we characterise as South Africa's prohibitionist approach to private security. Among other objectives, this Act seeks to "prohibit mercenary activity; to regulate the provision of assistance or service of a military or military-related nature in a country of armed conflict; to regulate the enlistment of South African citizens or permanent residents in other armed forces; to regulate the provision of humanitarian aid in a country of armed conflict; to provide for extra-territorial jurisdiction for the courts of the Republic with regard to certain offences; to provide for offences and penalties". ${ }^{32}$ From these objectives, the Act constructs a twopronged prohibitionist framework. First, it criminalises all acts that are deemed mercenary in nature. ${ }^{33}$ These acts include the "direct or indirect recruitment, use, training or support of combatants in armed conflicts." It also prohibits the negotiating or offering assistance (including rendering service) to an armed conflict or regulated country; providing any assistance or rendering any service to a party to an armed conflict or regulated area; recruiting, using, training, supporting or financing a person to provide or render any service to a party to an armed conflict or regulated area; and performing any other act that has the result of furthering the

30 Prohibition of Mercenary Activities and Regulation of Certain Activities in Country of Armed Conflict Act 27 of 2006. This Act repealed the Regulation of Foreign Military Assistance Act 15 of 1998. In terms of its long title, the RFMA was aimed at regulating "the rendering of foreign military assistance by South African juristic persons, citizens, persons permanently resident within South Africa and foreign citizens rendering such assistance within the borders of South Africa". For the discussion on RFMA, see Bosch and Maritz 2011 PELJ 75.

31 See Ahmadou and Gumedze 2008 www.iss.co.za.

32 See the Preamble of the Mercenary Act.

33 Section 2 of the Mercenary Act. 
military interests of a party to an armed conflict or in a "regulated country".34 Interestingly, and in furtherance of its prohibitionist posture, the Act adopts some of the elements of definition of a mercenary found in regional and international instruments such as the "object of private gain; the participation, directly or indirectly in acts aimed at furthering armed conflicts; instigating or supporting rebellion against legitimate governments, coup d'etat and the undermining of constitutional order, sovereignty and territorial integrity of states". ${ }^{35}$

Secondly, it seeks to exercise control over persons or companies or individuals that may legitimately engage in such activities abroad by establishing a licensing process. Thus, a major aspect of this Act is the requirement for the registration of private security entities by the National Conventional Arms Control Committee established under the National Conventional Arms Control Act. ${ }^{36}$ In addition to this, the Act has extra-territorial application: it regulates the activities of South African registered private military security companies in foreign lands. So, while under sections 3, 4, and 5 the Act prohibits the rendering of assistance and certain services, the enlistment of South Africans in armed forces other than the South African Defence Force, and the provision of humanitarian services in countries where there is an armed conflict or in a regulated country, persons seeking to perform or participate in such acts may apply for authorization through a procedure set out in section 7.37 The Act retains the functions of the National Arms Control Committee as the authorisation body. Interestingly, one of the extra-territorial components of the Act (section 11) is that acts committed outside South Africa by South African companies, citizens or permanent citizens may be tried as though they were committed in South Africa. ${ }^{38}$ In essence, this means that a violation of the law by these entities outside South Africa's borders subjects them to the jurisdiction of South Africa's legal system. This would be in addition to the jurisdiction exercisable by any other affected state under either the domestic law of such a state or international law.

34 Juma "Mercenarism" 218.

35 Juma "Mercenarism" 218.

36 National Conventional Arms Control Act 41 of 2002.

37 See Juma "Mercenarism" 219.

38 Juma "Mercenarism" 219. 
In general terms, however, the legal framework created by this Act is more prohibitive than regulative; it harshly frowns upon private military securitisation and mercenarism. Such a hostile approach to the private military industry in South Africa might have been justified by general suspicion and distrust of these entities in Africa at the time this law was promulgated. But times have changed and many of the challenges that South Africa faces also create opportunities that must be urgently seized by the government. South Africa needs to overcome its ambivalence to market-oriented approaches to security and deal with the smugness and lassitude inherent in its security reform agenda. Apartheid and the struggles to overcome it may have created apathy towards neo-liberal tendencies, but the reality of global security and the economic opportunities that privatisation in the sector presents have made it inevitable for the independent South Africa to shift its policy. In our view, the shift has become evident in the recently promulgated Defence Review of 2012. The question, however, is how this indicator may nudge normative development towards embracing the liberal trends in private security regulation. Moreover, the fact that the document is merely a draft inevitably triggers debate on whether the final policy document will accommodate the imperatives of global change in private security regulation.

\subsection{Draft South African Defence Review (2012)}

As already said, the government produced two policies before 2012, the 1996 White Paper on Defence and the 1999 White Paper on Defence Related Industries. In the recent past these two policies have become punch-bags for their critical shortcomings in failing to meet contemporary challenges in the defence and security sectors. The need to constantly review official policies and the debates generated by mercenary and private military and security acts on South Africa's soil necessitated the formulation of a new policy framework to supplant these two official documents. On 12 April 2012, the South African Ministry of Defence and Military Veterans published a draft South African Defence Review 2012 (hereinafter the Defence Review) for the purposes of public engagement and debate. The Defence Review is essentially a tentative document aimed at the formulation, development and 
implementation of a new strategy and policy for South Africa's defence. The eventual aim is to replace the current defence policy with a new policy framework that appropriately incorporates contemporary practices, strategies and approaches in defence and security whilst simultaneously responding to major developments in the global defence environment. Accordingly, the Review covers vast areas related to national defence and security, most of which do not fall within the purview of this discussion.

As regards PMSCs, the Defence Review justifies the need for a renewed debate on the role of private players in the security sector, given that a number of "South African private security companies continue to be contracted by foreign countries to operate in conflict zones, usually protecting prominent individuals, critical infrastructure, property and strategic resources". ${ }^{39}$ The review envisions the debate being extended to the nature of the relationships such companies could have with former and currently active members of the South African National Defence Forces as well as other state armies and governments in Africa and beyond. Further, the review predicts that "the global involvement of South African private security companies or South African citizens, particularly in defence transformation, peacekeeping and peace building in conflict and post-conflict areas will continue into the foreseeable future." ${ }^{40}$ This statement constitutes an important official admission of the increasing involvement of South African corporate private military security entities in conflict zones. It can be argued that the fact that the Defence Review identifies the issue of mercenarism and private military security as pressing concerns suggests that there is need for their effective regulation. The Defence Review therefore predicates the need for intellectual debate on policy and normative change contemporaneous with developments in defence and security in South Africa and across the globe.

We have suggested that the Review indicates a shift in South Africa's policy on private security that accommodates regulation rather than prohibition. As a matter 
of critical importance the Review, first of all, acknowledges the difference between mercenaries and PMSCs, although it fails to describe each category satisfactorily. The benefit of making the distinction is obvious - it paves the way for dealing with PMSCs as distinct phenomena, thereby allowing South Africa to establish regulatory frameworks that do not disturb the regional and international regimes that criminalise mercenary activities. Undoubtedly there are many private entities operating in African conflict zones whose activities are questionable. Such entities violate domestic as well as international law in several respects and must be dealt with severely. Thus, the distinction needs to be much clearer and should, if possible, go down to the demarcation of the activities of an entity's personnel and the services it provides. ${ }^{41}$ The controls must be stricter if the entity will be operating in a conflict zone or providing military services. This implies that there should be a distinction even among the PMSCs themselves. Apart from the foregoing, the distinction in the Defence Review is welcome because it opens up a new perspective on the way South Africa and perhaps Africa at large should view the role of private entities in boosting their security needs.

Apart from acknowledging the distinct nature of PMSCs, the Defence Review points to the needs for normative intervention. It suggests that existing policy priorities and the legal regulatory framework might need to be upgraded in order to properly capture evolving and contemporary developments in this sector. Indeed, South Africa might need to respond to this call by urgently establishing a normative framework to regulate its burgeoning private security sector. This being the case, it may be useful to examine how developments at the international level that affirms the global commitment towards the regulation of PMSCs might influence such an endeavour.

41 In international humanitarian law the distinction falls on legal status - whether PMSC personnel should be regarded as civilians or combatants. Ideally they should be civilians and not combatants. Thus, when they directly participate in combat, they lose their civilian status. IHL has developed complex guidelines on determining "direct participation". See ICRC 2009 www.icrc.org 872-991. 


\section{$4 \quad$ Changes in the global arena}

In this section we examine international developments that signify a change of attitude towards the privatisation of security and the willingness to accommodate regulation rather than prohibition. We posit three trends that manifest this change. The first encapsulates the efforts within the United Nations to develop a multilateral treaty specifically dealing with PMSCs, while maintaining the legitimacy of the antimercenary laws. These efforts are mainly resident within the UN Working Group on the Use of Mercenaries as a Means of Violating Human Rights and Impeding the Exercise of the Right of Peoples to Self-determination (the 'Working Group'). ${ }^{42}$ The centrepiece of these efforts is the recent promulgation of the Draft Convention on Regulation Oversight and Monitoring of Private Military and Security Companies. ${ }^{43}$ Secondly, change patterns are explicit in the plethora of soft-law instruments crafted through collaborative efforts of governments and regional power blocks as well as leading stakeholders in the private security industries. We single out for discussion the Montreux Document, ${ }^{44}$ produced in 2008 and largely regarded as a template for acceptable practices in engaging and monitoring the services of PMSCs. ${ }^{45}$ Thirdly, the ascendancy of self-regulatory frameworks into mainstream discourse on PMSC regulation cannot be ignored. Regional and national associations formed by PMSCs have developed codes of conduct that govern the activities of their members. In as much as these codes were initially meant to steer the discourse away from the dreaded subject of mercenarism and cushion the industry against regulatory overreach, they provide the moral tenor that has galvanised the evolving shift in perceptions and attitudes towards PMSCs. In fact, it is through these associations that we have witnessed the strongest claims to the differentiation which exists between mercenarism and PMSCs.

42 HRC Res 2005/2. The activities of the Working Group are posted on their web page (UN OHCHR Date Unknown www.ohchr.or).

43 UN 2009 mgimo.ru (hereinafter the Draft Convention).

44 See Montreux Document on Pertinent International Legal Obligations and Good Practices for States Related to Operations of Private Military and Security Companies During Armed Conflict, Annex, addressed to the Secretary General (2008) (Montereux Document).

45 For an in-depth discussion of the Document, see Cockayne 2009 JCSL 401. 
It may be worthwhile to mention that the trends above do not complement each other: they exist in separate worlds despite targeting similar problems. And that, all along, has been the main inhibitor to the establishment an international regime for the regulation of PMSCs. The UN Working Group process eschews the self-regulatory mechanisms and views them as being sympathetic to camouflaged forms of mercenarism. ${ }^{46}$ On the other hand, proponents of the Montreux Document are equally ambivalent to the Working Group process and its efforts to establish a binding multilateral framework for PMSCs. For our purpose, however, these trends illustrate the shift in thinking around PMSC regulation and may very well provide ample lessons for developing domestic policy and law. Let us examine in a more substantive way how these trends play out in the context of normative change regarding PMSCs.

\subsection{Normative developments prior to 2005}

Few may dispute the fact that normative development at the international level is slow and often belated. Likewise, the values which spur normative change take time to garner enough probity among the divergent political constituencies that make up the international community. This explains why international treaties have a long gestation period. The challenges of building consensus are numerous, as is the complexity of generating an acceptable normative framework even on subjects that are not disputed. As far as security goes, the wheels turn even slower. When the United Nations adopted the International Convention against the Recruitment, Use, Financing and Training of Mercenaries (the UN Mercenary Convention) in $1989,{ }^{47}$ it was because African states were able to build a consensus around the need to protect their democracies from the threat of mercenarism. ${ }^{48}$ Indeed, the same African states had signified their commitment to similar values by adopting their own

46 See eg the Report of the Working Group on Mercenaries (HRC 2007) para 36 (noting the human rights violations committed by PMSCs in Iraq).

47 International Convention Against the Recruitment, Use, Financing and Training of Mercenaries (1989) (UN Mercenary Convention). The Convention did not come into force until 2001 when Costa Rica acceded to it. Currently, the Convention has only 28 ratifications and nobody has ever been prosecuted under its regime.

48 Zarate 1998 Stan J Int'l L 75. 
version of a mercenary convention way back in $1977 . .^{49}$ Beyond the African continent, a commitment of this nature had already been made by the international community even before the African Mercenary Convention was passed. In 1968, the UN General Assembly had adopted a resolution which declared the practice of using mercenaries an offence..$^{50}$ Two years later the Assembly adopted the Declaration on the Principles of International Law Concerning Friendly Relations and Co-operation among States, which imposed on states the "duty to refrain from organising armed groups, including mercenaries, for incursion into the territory of another state". ${ }^{51}$ These developments were consistent with the prevailing ideology of prohibition and helped shape the norms that evolved thereafter.

By adopting the Convention, the international community made a statement about values which they considered important to their co-operative project of maintaining international peace and security. Given that mercenary activities were regarded as forms of violence and a threat to international peace and security, the Convention was seen to fulfil an important international function. Its scheme effectively outlawed such activities and enjoined states to ensure that their territories were not used to perpetrate any acts of its kind. ${ }^{52}$ It went even further and forbade the recruitment, use, financing and training of mercenaries. ${ }^{53}$ Although the Convention could not come up with an accurate definition of a mercenary, so as to demarcate the precise contours of the prohibition regime it established, ${ }^{54}$ this did not suggest any derogation from the values it sought to protect or any ambiguity in the intention of states sponsoring it. It merely pointed to the complexity of the mercenary question and the contradictions within the neo-liberal frame when it comes to security and profits.

49 See Gumedze 2007 ASR 22; Fallah 2006 IRRC 599.

50 Implementation of the Declaration on the Granting of Independence to Colonial Countries and Peoples UNGA Res 2465, 23UN GAOR Supp (No 18) at 4 UN Doc A/1218 (1968) (UN GA Res 2625).

51 UN GA Res 2625.

52 See Juma "Mercenarism" 209 (discussing a 10 of the Convention).

53 Article 5 of the UN Mercenary Convention.

54 Article 5 of the UN Mercenary Convention; Desai 2005 USFL Rev 825. 
The Convention's prohibitionist approach was undoubtedly a spirited reaction to the ambivalence towards privatisation in the security sector that was prevalent at the time. Indeed, the threat that mercenarism and other private security or military outfits were seen to pose to the universal values of peace had for a long time appeared genuine and understandable. However, significant changes in the international normative order, which have occurred in the past decade, seem to indicate that the value system is also changing. Evidently, the international community is gradually accommodating the changes brought about by globalisation and the free market in its approach to maintaining international peace and security. Concomitant with these changes has been the community's growing affinity to security options and methods of deployment that are less hostile or ambivalent to private actors. Powerful nations as well as regional organisations have ratcheted up their use of PMSCs, forcing the tide to rise in favour of increasing privatisation in military projects, despite international norms. For example, the African Union, a major proponent of the anti-mercenary crusade, has itself used PMSCs in several peace projects. ${ }^{55}$ For this reason, earlier laws such as the UN Mercenary Convention, the Geneva Conventions ${ }^{56}$ and even the rules of customary law ${ }^{57}$ that had entrenched the international distaste of mercenary activity and decreed against the involvement of private entities in war are coming under severe strain. ${ }^{58}$ Indeed, the antimercenary crusade which the international community had bound itself to when the Mercenary Convention and other instruments were passed is dissipating as PMSCs gain more acceptance. ${ }^{59}$ These developments have entrenched the difference between mercenarism and PMSCs, thus minimising the focus on anti-mercenary law. As one scholar argues, the distinction has "created a discursive opportunity for the

55 The AU's peace operations in Sudan were supported by Pacific A \& E and Medical Solutions, which provided transport and logistical communication services. See Pattinson 2010 Int'l Theory 9. For a complete discussion of the role of PMSCs in African Union operations, see Holmqvist Private Security Companies 50. See also Spearin 2011 Int'l Peacekeeping 196.

56 See eg a 47 of Protocol Additional to the Geneva Conventions of 12 Aug 1949 and Relating to the Protection of the Victims of International Armed Conflicts (1979) (Additional Protocol I), which denied the benefit of prisoner of war status to mercenaries. This article crafted the first definition of mercenary that was adopted in all subsequent regional and international treaties. See also UN GA Res 2625 approving the Declaration on Principles of International Law Concerning Friendly Relations and Cooperation among States in Accordance with the Charter of the United Nations.

57 See Percy Mercenaries 216.

58 See Shearer Private Armies 16.

59 See eg Ebrahim 2010 BU Int'/ L 210. 
development of new international regulations that endorse the legality and legitimacy of contracted business and their employees using armed force in regions of conflict." ${ }^{60}$ Added to this evolving phenomenon is the fact that the anti-mercenary laws are grossly ineffective. Just about 30 states have ratified the UN Mercenary Convention, ${ }^{61}$ signifying the lack of interest in the prohibitionist approach. Furthermore, none of these laws have clear definitions of who a mercenary is, and they are completely opaque to the corporate organisational structure that private entities have assumed in the recent past. Thus, they are unhelpful when it comes to dealing with PMSCs. These drawbacks, complemented by the proliferation of PMSCs all across the globe, more than underscore the need for new regulatory frameworks. ${ }^{62}$ Let us now examine how the international community has responded to this need, by analysing the trends that we mentioned earlier.

\subsection{The Draft International Convention on the Regulation Oversight and Monitoring of Private Military and Security Companies}

As we have already intimated, the prohibitionist thinking prevailed in the United Nations for just about two decades. Up until 2005, when the UN Working Group was constituted, the ruling idea was that of prohibition. But the Working Group has charted a new course, coming up with a draft law which acknowledges the role of PMSCs and embodies the principles of regulation. This proposed draft law marks a turning point in the UN's approach to the PMSCs question. It affirms the legality of PMSCs, as opposed to mercenaries, and establishes a scheme for distinguishing prohibited mercenary activities from the permissible activities of PMSCs, while directing the attention of the international community to the need to eliminate conditions that allow violations of human rights by PMSCs and their personnel to go unpunished. The Draft Convention deals with important aspects of what one might regard as modern PMSCs law such as state responsibility, the obligations of international humanitarian law, the criminality of certain acts, human rights, and the establishment of enforcement and monitoring mechanisms. Since these issues have

60 Krahmann 2011 Millenn J Int Stud 345.

61 See Gichanga Fusing Privatisation 2.

62 See Mehra 2009-2010 Pac McGeorge Global Bus \& Dev L 327. 
been dealt with elaborately in several studies, ${ }^{63}$ our interest here is limited to the illustration of how this initiative changes the global perspective regarding the regulation of PMSCs.

Perhaps the place to begin in the analysis of this law is what it claims to be its purpose. It is here that the tone for regulation is set and a clear break from the prohibitionist approach can be discerned. The Convention outlines its main objective to be the need to fill the "important gaps...in national and international legal regimes applicable to private military and security companies". ${ }^{64}$ Further, the Convention outlines key factors and conditions necessary for the establishment of a robust regulatory framework. These include the creation of a regulatory framework that would ensure that PMSCs observe international humanitarian and human rights law; establishing systems of regulation that target, not only the conduct of PMSCs, but their relationship with states as well; demarcating roles and functions so that PMSCs do not undertake functions that fall within the exclusive competence of states; harmonising the full breadth of international instruments that have a bearing on PMSCs; and setting agreeable legal standards for the regulation of PMSCs. ${ }^{65}$

The Draft Convention then proceeds to establish rules regulating the relationship between states and PMSCs and minimum standards for the activities of these companies. A wide range of issues is dealt with, including what constitutes inherent government functions and the notion of direct participation in hostilities; prohibited activities and the role of states in this regard; state responsibility; and the notion of effective remedy. Its rules also create supervisory mechanisms at the international as well as national levels. In this regard, it proposes the establishment of an oversight committee which will not only receive and review reports on the implementation of the Convention, ${ }^{66}$ but also conduct enquiries upon receiving

63 See eg Prado 2012 Criminal Justice Ethics 262; Prado 2008 JC \& SL 429; Juma 2011 Law Democracy \& Development 182; White 2011 Hum Rts Rev 133.

64 Preamble, para 21 of the Draft Convention.

65 See Juma 2011 Law Democracy \& Development 188. See also aa 2, 7, 11 and 23 of the Draft Convention.

66 Article 33 of the Draft Convention. 
reliable information of "grave and systematic violations" of the Convention. ${ }^{67}$ In addition, it establishes an individual or group complaint procedure similar to those in human rights treaties. ${ }^{68}$ At the centre of its regulatory scheme are states. They are required to take "legislative, administrative and other measures as may be necessary to ensure that PMSCs and their personnel are held accountable for violations of applicable national and international law" ${ }^{69}$ Further, a state is enjoined to "establish comprehensive domestic regimes for regulation and oversight over activities in its territory of PMSCs and their personnel, in order to prohibit and investigate illegal activities as defined by this Convention as well as by relevant national law". ${ }^{70}$ This obviously has implications for states such as South Africa that are still holding to the prohibitionist approach, calling on them to switch gears and begin to accommodate PMSCs in their policy and legislative responses to security concerns.

The other aspect that might be of interest is the fact that whereas the draft law affirms the commitment of the international community to the UN Mercenary Convention in the Preamble, its approach to PMSCs regulation belies such a commitment. This is revealed by the manner in which it deals with activities that would ordinarily be mercenary in nature if performed by private entities and not the state. ${ }^{71}$ These activities are described as "unlawful activities" and not mercenary acts. ${ }^{72}$ In fact, the word mercenary is avoided completely. Even where the Draft Convention expressly prohibits the use of force by PMSCs to overthrow governments or to violate state sovereignty, ${ }^{73}$ an act which for a long time has been the hallmark of mercenary involvement in Africa, no reference is made to the existing prohibition frameworks. The only plausible explanation is that the drafters intended to subtly embrace the distinction that state practice has drawn between mercenaries and PMSCs. And by doing so, the drafters may have hoped to convey the message that the prohibitionist approaches of yesteryears weren't obsolete but remain directed at

67 Article 35 of the Draft Convention.

68 Article 34 of the Draft Convention.

69 Article 5 of the Draft Convention.

70 Article 12(1)(a) of the Draft Convention.

71 Article 2 of the Draft Convention. See also, White 2011 Hum Rts Rev 138 (suggesting that limiting some activities only to states may be problematic for advocates of the free market).

72 Article 2 of the Draft Convention.

73 Article 8(1) (a)-(d) of the Draft Convention. 
mercenaries and not PMSCs. The difficulty here is that an entity that commits these wrongful acts is still classified as a PMSC and not a mercenary, thus blurring the distinction. Moreover, the upshot of this approach is to diminish the relevance of "mercenary" as a term in security discourse.

There is no doubt that the UN efforts to establish a binding international framework should be supported. Moreover, considering that the involvement of PMSCs in international duties, such as peacekeeping, is set to increase rather than decrease, the preference for a binding multilateral regime cannot be overstated. ${ }^{74}$ Therefore, even as we advocate for national laws we are conscious that a domestic regime can be most effective if it is based on international standards. Moreover, most PMSCs are transnational organisations and their operations span the globe. Because of this spread and the fact that they may forge different kinds of relationships with states, fragmented approaches to their regulation inevitably lessen accountability and diminish the effect of law. For example, it may be difficult at times to ascertain the difference between a "sending state" and a "host state" for the purposes of apportioning responsibility. ${ }^{75}$ Also, regulations in one state cannot constrain PMSC operations in another state. These apart, the PMSC phenomenon feeds into the perennial problem of establishing accountability for multinational corporations under international law. The dominance of multinational corporations in our present world is indisputable. But their operations do not always yield benefits, and accountability remains a problem. Some organisations see this as a problem that requires international normative intervention. The UNDP, for example, has suggested that accountability may be established if multinationals are brought "within the framework of global governance, not just a patchwork of national law rules or regulations". ${ }^{76}$ We accept this broad analysis but doubt if it can deliver on enforcement. So, while we agree that to fully regulate PMSCs an international framework should be in place, domestic mechanism are still needed to complement it and give it the necessary enforcement edge. This is recognised by the Draft Convention, which enjoins states to pass domestic law that confers the jurisdiction

74 See Gichanga Fusing Privatisation 6.

75 See Cockayne 2009 JCSL 401.

76 UNDP 1999 100, cited in Mehra 2009-2010 Pac McGeorge Global Bus \& Dev LJ 332. 
to oversee the operations of PMSCs taking place within their territories on national structures. ${ }^{77}$ Moreover, failure to enact a domestic law creates an accountability gap that will only allow for impunity to go unpunished.

\subsection{The Montreux Document on Pertinent International Obligations and Good Practices for States Related to the Operation of Private Military and Security Companies during Armed Conflict}

The Montreux Document represents one of the most significant efforts to establish a non-binding but widely respected regime for the regulation of PMSCs. It was developed by the efforts of both the Swiss government and the International Committee of the Red Cross (ICRC) through what was dubbed the 'Swiss Initiative'. The initiative was technically a consultative process involving governments, the PMSCs and the civil society in seeking a regulatory framework for PMSCs by clarifying their obligations under human rights law and international humanitarian law. The initiative culminated in the production of the Montreux Document in 2008. ${ }^{78}$ The Document is not a binding instrument but a mere statement of recommendations meant to bolster the state's ability to control PMSCs activity. From an ideological standpoint the Document was a major triumph for PMSCs because it signalled the international community's acceptance of private security operatives as legitimate players in the context of an armed conflict. For this reason PMSC organisations have been quick to welcome it. They have predicted that the Document will form the basis for developing an industry-wide code of conduct that will have a wider application than the existing self-regulatory mechanisms. ${ }^{79}$

The Document has two parts. The first part contains 27 obligations that states have to assume with regards to their regulation of PMSCs. These obligations generally

77 Article 4(5) of the Draft Convention.

78 The seventeen countries initially involved in the production of this document were: Afghanistan, Angola, Australia, Austria, Canada, China, France, Germany, Iraq, Poland, Sierra Leone, South Africa, Sweden, Switzerland, the United Kingdom, Ukraine, and the United States of America. In addition, a sizeable number of PMSCs and NGOs were also involved. See Juma 2011 Obiter 77. See also Cockayne 2009 JCSL 401.

79 See Stürchler 2008 JIPO 10. 
require that states ensure PMSCs' compliance with international law. They are therefore enjoined to enact appropriate legislations that are in conformity with international instruments; to create methods of enforcement of the law so enacted, including the investigation and prosecution of offenders; to ensure respect for international law; and to take responsibility for the activities of PMSCs they contract, including the readiness to provide reparations whenever necessary to parties who suffer as a result of PMSC activity.

The second part contains what is referred to as good practices and is meant to "provide guidance and assistance to states in ensuring respect for international humanitarian law and human rights law" and to promote responsible conduct in states' relationship with PMCs operating in their territories. There are $73 \mathrm{good}$ practises listed. ${ }^{80}$ But in all these, the prime responsibility rests with states. As far as contracting states are concerned, their responsibility for violations of humanitarian or human rights law by PMSCs will arise where the PMSC is incorporated in the regular armed force; where the PMSC is under the command of the state; where it is empowered to exercise elements of governmental authority, or to perform functions "normally" conducted by organs of state; and where the PMSC is acting under the instructions of the state. ${ }^{81}$ It is understandable that the drafters of the Document intended to clarify the confusion around state responsibility, but the manner in which the obligations are crafted may indeed be the greatest weakness of the instrument. Leaving responsibility on the shoulders of states may be counter-productive. For example, states with weaker legislations or those who delay in enacting appropriate laws will not be able to fully participate in the framework created by the Document. The result will be that PMSCs will move to such states to avoid strict oversight. Other states may have an interest in shielding PMSCs from public oversight because they perform sensitive duties. They may therefore enact laws that give immunity or restrict the disclosure of information to the public. (Incidentally, this loophole has been sealed by the Draft Convention). The Document should have given some recognition to civil society, especially in monitoring the accountability of PMSCs in

80 Stürchler 2008 JIPO 9.

81 Paragraph 7 of Part 1 of the Montreux Document spells out this obligation in rather elaborate terms. 
conflict situations, and established minimum standards that states must comply with, no matter what.

\subsection{Self-regulation}

Concomitant with the recent normative developments both at the United Nations and within the various formations working towards creating regulatory standards for PMSCs are the efforts by the industry to rid itself of the label of mercenarism and construct a new businesslike image for itself. Underlying these efforts is the considerable influence that the industry has been able to exert on policy formulation with regard to military activity in conflict zones. Part of their strength lie in their international presence ${ }^{82}$ and the fact that they find univalled favour with powerful governments in the north. ${ }^{83}$ But the industry has proceeded cautiously, first by recognising the validity of the misgivings about the conduct of its members and secondly, by proclaiming its willingness to enforce accountability through in-house procedures (self-regulation). Indeed, the message seems to be that self-regulation is possible because they are transparent, legal and have the capacity to regulate themselves. It is no secret that the main driving force is the desire to keep statedirected regulatory and oversight schemes at a minimum. PMSCs are no different from other business entities in this regard. Most self-regulatory systems are born out of the need to pre-empt government regulations - what has been referred to as the "shadow hierarchy" argument. ${ }^{84}$ The bad publicity the PMSC industry got in Iraq, Afghanistan and Africa have no doubt created a potential for the adoption of stringent regulatory controls by governments. But whether the publicity of events from these areas led to more cover-up as has been suggested by some scholars is a matter for debate. ${ }^{85}$

82 By 2008, PMSCs had a presence in over 110 countries. See Steinhoff "What are Mercenaries?" 19.

83 See generally Cockayne et al Beyond Market Forces 45; Bryton 2002 J Int Aff 303.

84 See Nevers $2010 \mathrm{~J}$ Pub Pol'y 222. See also Prakash 1999 Business Strategy and the Environment 323; Cashore, Auld and Newsom Governing Through Markets 27.

85 See eg Singer Corporate Warrior 222. 
In response, the industry has developed a full array of internal management systems and controls through cooperation. For example industry players who are members of the British Association of Private Security Companies (BAPSC), the International Peace Operations (IPOA), the Private Security Company Association of Iraq (PSCAI) and the newly formed Pan African Security Association (PASA), have developed systems of controls and even some binding Codes of Conduct. IPOA for example, which has a membership of over 40 companies, has a Code of Conduct that sets out the members' responsibility on human rights, transparency, arms, safety and work place relations. ${ }^{86}$ The organisation has a Standards Committee which is tasked with investigating any alleged infractions of the Code. However, the most stringent measure that the Committee may take against a member is to recommend expulsion. The BAPSC, on the other hand, require that its members provide service with "high professional skills and expertise whilst recognising that the countries where they are operating have inadequate frameworks." ${ }^{187}$ The organisation is heavy on the promotion of good relations between its members and the government of the UK and international bodies, and requires compliance with the values, interests and laws of the countries where they operate.

Considering the gravity of the human rights violations that have been committed by some of these companies, such measures are laughable. Apart from being too permissive, the mechanisms are designed to achieve results only with the consent of the members. Moreover, not all companies operating in conflict zones are members of such associations. One analyst has described the self-regulation mechanisms as nothing more than statements on paper. ${ }^{88}$ The regrettable fact is that although the codes of conduct produced by these associations cannot override the obligations created by international human rights law and international Humanitarian law, ${ }^{89}$ the

86 Mesner "Working Towards Effective Legislation" 166.

87 See BAPSC 2008 www.org.uk. One of the key objectives of the association is stated to be that of providing guidance on the substance of the need to comply with "international legal statutes". Obviously, with limited regulatory regimes at the international level, the association is aware that its members may be best served by the self-regulatory framework.

88 Cockayne et al Beyond Market Forces 45-46.

89 Gillard 2006 IRRC 548. 
constituencies that subscribe to them are unlikely to support the establishment of a binding multilateral framework.

\section{Towards a new South African approach to PMSC regulation}

The discussions in the above paragraphs easily lead to the conclusion that the international community no longer regards PMSCs as mercenaries and that their deployment in conflict zones may become the norm rather than an exception. Also, that there is belief among many states that they can control the activities of PMSCs, especially their use of force, through national laws. These conclusions, however tenuous they might appear, represent a change in the way the world views PMSCS and privatisation in the security sector in general. Concurrent with this evolved thinking is the realisation that existing normative structures, especially those that hitherto informed the prohibitionist notions and anti-mercenary ideas, are generally impotent in the face of the challenges that the phenomenon now poses. Taking all of these things together, one could view the PMSC phenomenon as presenting challenges as well as opportunities - challenges because there is a need for greater accountability in the industry, and opportunities because states can now expand their security infrastructure in ways that enable them to participate in the global arena without political inhibitions. It is our view that a response to both the challenges and the opportunities should invoke normative changes sensitive to the newfound willingness to liberalise the security sector.

The South African Defence Review 2012 is an indicator of this changed sensibility since the 1994 White Paper and the 1996 Defence Review were formulated. Although these earlier policies carry some deficit, such as a lack of clarity on the role of South African-based institutions in Africa's security architecture and the stunted progress of the non-offensive defence capabilities programme, ${ }^{90}$ they ensured that security reform remained high on the list of priorities of the post-apartheid government. The Defence Review 2012 has entered on this path, but with a lack of dogmatism that opens its reform agenda to new ideas. And that is why its

90 See Roux "Revision of the South African Defence Review" 283-284. 
accommodative approach to PMSCs is a breath of fresh air, so to speak. The Defence Review now provides an opportunity to explore contemporary and diverging issues relating to private military security from a legal point of view. And in a rather overt way, it encourages the nation to ponder the possibility of putting in place a legislative framework dealing with PMSCs that takes on board all the imperatives of regulation consistent with the emerging sensibilities on security reform. In the following sections we attempt to justify this view and to suggest some broad imperatives that such legislation would cover if it were to be enacted.

\subsection{Justifying the establishment of a legislative framework}

South Africa was lauded for being the first African nation to enact a law on mercenaries - the Prohibition of Mercenary Activities and Regulation of Certain Activities in Country of Armed Conflict Act 2006. ${ }^{91}$ But as we have already shown, there are serious limitations in the Act's regulatory framework. Furthermore, like the related international treaties, it is of little practical use in relation to PMSCs. However, the fact that there is an existing legal framework is somewhat of a blessing in the sense that it allows for the interrogation of the effectiveness of the anti-mercenary law in the emerging context. The existence of this largely moribund law indicates a general willingness of South Africa's political elite to deal with the challenges that privatisation of security brings. Apart from the dearth of legal frameworks to deal with the challenges that the PMSC phenomenon pose, it may be equally important to register the broader economic benefits of establishing standards of regulation that do not necessarily stifle the economic enterprise. Obviously, adopting a more liberal approach to PMSCs may strategically position South Africa to take advantage of globalisation and its free-market system and to expand its presence in the global security industry. ${ }^{92}$

91 See eg Franklin 2008 Transnat'l L \& Contemp Probs 246.

92 The use of PMSCs to deal with the menace of piracy off the coast of Somali demonstrates their increased presence in the international security debate, but also the fact that they generate economic benefits. See eg Spearin 2012 JICJ 823. 
Primarily, however, establishing effective regulatory mechanisms engender the promulgation of a legislative regime that creates standards aimed at improving accountability for the industry. And as already mentioned, the task of instituting accountability cannot be left to international regulatory frameworks alone. The latter should be complemented by domestic interventions. And this is what justifies our call for legislative action at the national level. In our view, a domestic regulatory regime that can meet these challenges must be effectively capable of upholding universal standards of human rights law and international humanitarian law, while adapting to the emerging demands of the global security landscape.

\subsection{Elements of the envisioned regulatory framework}

We believe that time has come to establish a permissive, albeit effective regulatory framework for PMSCs in South Africa. The basis of doing this should be the recognition of PMSCs as legitimate actors in the security arena. This recognition is captured most succinctly by the discursive shift that we earlier alluded to, which has moved the discourse away from the anti-mercenary and prohibitionist approach to the regulatory one. This shift has exposed the normative loopholes in a potentially vast mine-field of concerns regarding these entities. While with mercenaries it was easy to simply prohibit, with PMSCs, legal standards of practice and responsibility for violations of human rights and rules of international humanitarian law have to be established. An effective and legitimate regulatory framework must therefore deal with a plethora of concerns, the most important of which are: the preliminary issue of defining these entities, determining their legal status both under international human rights law and humanitarian law, their obligations and responsibilities, and the nature and implications of the relationships between private military companies and state and non-state actors in either international or non-international armed conflict. These are matters that require normative certainty. Although an argument could be made that since the Defence Review merely encourages debate on these issues, a sectoral approach to regulation, such as we see in United States and other European countries, may suffice. We dispute this contention. In the United States, 
for example, there are over fifty laws that affect PMSCs. ${ }^{93}$ Since they address different issues, effective enforcement is difficult to attain. In our view, sectoral legislations are patchy and un-coordinated - they fail to "provide a comprehensive system of human rights standards". ${ }^{94}$ Also, achieving maximum protection for individuals or groups who suffer from violations of human rights or rules of international law and enforcing such rules may be cumbersome. Given these drawbacks it may be appropriate to conclude that the Defence Review 2012 envisions the promulgation of a single legislative framework establishing key regulatory measures for PMSCs, from which other regimes may derive their legitimacy.

Setting out precise and conclusive content of the proposed law is not our intention. The objective here is to analyse some broad aspects of the law with a view to showing how its regime could fit within the framework of change we alluded to earlier - the change from prohibition to regulation. One of the main factors that have propelled the transition is the affirmation of the status of PMSCs as essentially civilian and not military. This is key to defining the scope of the new law's jurisdiction. Correlative to the issue of status is the nature of the services that PMSCs could be lawfully contracted to perform. This has been something of a grey area, where actual practice conflicts with the intentions of law. The Montreux Document, for example, describes them as companies that offer "military and security services", thus conflating their roles. ${ }^{95}$ Such an inclusive description of services that PMSCs could offer is problematic for a national regulatory framework and should be avoided. The conflation might render it difficult to establish the necessary distinction between PMSCs and mercenaries, and the status of PMSC personnel under international humanitarian law. ${ }^{96}$ Further, it might compromise efforts to create a regulatory scheme that may be seen as compatible with the existing anti-mercenary

93 See Hurst 2010 S Cal L Rev 470.

94 Hurst 2010 S Cal L Rev 470.

95 Montreux Document para 9.

96 Whether PMSCs can be classified as "combatants" or "civilians" under international humanitarian law depends on the kinds of services that they provide in a conflict situation. And this has been very controversial. See Bosch and Maritz 2011 PELJ 77. The new law could lessen the confusion if it limits the roles of PMSCs to purely civilian functions, although this may not be easy to attain. See Gumedze Addressing the Use of Private Security 3. 
law. Moreover, if the state is to retain its monopoly of force, crucial military activities must not be outsourced but be left within the domain of civic responsibility. It should be remembered that part of the reason why some scholars have been sceptical about privatisation is that it allows for all manner of individuals and groups to get access to military capabilities through the open market. ${ }^{97}$ The new law must allay these fears by establishing a tight regime that limits PMSCs to acceptable support roles that do not compromise the state's monopoly of the use of force and diminish the responsibilities that go with it. ${ }^{98}$ In this regard, the proposed law could avoid the omnibus prohibition based on "security services" and "non-security services" envisaged by the South African Mercenary $A c t^{99}$ and delineate functions along the same lines as the Draft Convention, by prohibiting PMSCs from performing functions that are "inherently governmental". ${ }^{100}$

What then are the important elements that should be canvassed by this law? Key issues that immediately come to mind are standards of accountability for violations as mentioned, access to judicial remedies for violations committed by PMSC personnel, and administrative imperatives such as licensing and monitoring. As stated above, the standards of accountability should form the core of the new law. And South Africa does not need to re-invent the wheel but could borrow the design from existing templates. This immediately raises the question of how the new law should relate to other legal frameworks, codes of conduct and soft-law instruments, such as the Montreux Document. One thing that must be borne in mind is that there

97 See eg Singer Corporate Warrior 7.

98 Some scholars have suggested that the reason why states hire PMSCs is to avoid responsibility or circumvent national law. See Bosch and Maritz 2011 PEL 77.

99 South Africa's Mercenary Act, s 1(1) defines "security service" to include " (a) Protection or safeguarding of an individual, personnel or property in any manner; (b) giving advice on the protection or safeguarding of individuals or property; (c) giving advice on the use of security equipment; (d) providing a reactive or response service in connection with the safeguarding of persons or property in any manner; (e) providing security training or instruction to a security service provider or prospective security service provider; $(f)$ installing, servicing or repairing security equipment; $(g)$ monitoring signals or transmissions from security equipment; $(h)$ making a person or service of a person available, directly or indirectly, for the rendering of any service referred to in paragraphs (a) to $(g)$ or (i) managing, controlling or supervising the rendering of any of the services referred to in paragraphs (a) to $(h) "$.

100 Article 2 of the Draft Convention (functions which are "inherently governmental" include "direct participation in hostilities, waging war and or combat operations, taking prisoners, law making...and other functions that a state party may consider to be inherently state functions"). See a discussion of the Draft Convention in Juma 2011 Law Democracy \& Development 182. 
is much inconsistency in the codes and the soft-law instruments. Our suggestion is that South African law could benefit more if it positioned itself as an extension of the Draft Convention. In this regard, the new law could, for example, adopt the Draft Convention's construction of the law on responsibility that arises from the use of force ${ }^{101}$ its scheme for the protection of the victims of violations; ${ }^{102}$ and the elevation of the role of INGOs. ${ }^{103}$ Overall, the proposed law must establish minimum standards based on principles of human rights and international humanitarian law that is applicable to all PMSCs registered in South Africa. Any association that may wish to enact a code of conduct for its members will then have to ensure that its code conforms to uniform standards in the new law. Another aspect that the law should absorb in its enforcement scheme is criminal liability. We propose that the law should establish such liability for certain kinds of activities within the operational mandate of PMSCs. Such liability could be linked to domestic and international criminal justice systems. The element of universal jurisdiction must of necessity be incorporated so that PMSCs cannot escape liability by simply migrating into South Africa. A detailed discussion of the protective and criminal schemes envisaged here may be appropriate for another space. Below, we digest some of the key administrative imperatives that the new law could incorporate in its regulatory regime to give effect to the standards of accountability that it establishes.

\subsubsection{A regulatory body}

Several frameworks discussed earlier have encouraged states to establish national institutions responsible for monitoring PMSCs. For example, the Draft Convention enjoins states to create a governmental body that would act as "national centre for collection, analysis and exchange of information" on the activities of PMSCs. ${ }^{104}$ It does not indicate the kinds of structures that such a body should have, presumably leaving it to states to model their legislation in the form that suits their circumstances. South Africa's Mercenary Act did not establish any such body, but 
bestowed all functions to the National Conventional Arms Control Committee (NCACC) established under the National Conventional Arms Control Act 2002. It is still unknown how the NCACC could have been effective, because the rules of procedure have not been promulgated. The new law that we are proposing could create an opportunity to establish a robust institution that will carry out all the licensing and monitoring functions for PMSCs, and provide a focal point for PMSC regulation. African countries, though not entirely opposed to establishing similar legislative frameworks, have been slow to enact legislations of this kind. One example that South Africa could look at is the Sierra Leonean's National Security and Central intelligence Act passed in 2002. ${ }^{105}$ The Act created the Office of National Security (ONS), which is the pivotal organ for the regulation of all private security operatives. ${ }^{106}$ Apart from being the secretariat for all activities mandated by the Act, the ONS is responsible for licensing of all PMSCs in accordance with set regulations, and ensuring that PMSCs comply with the Standard Operating Manual for Private Security Companies (SOP) promulgated in 2006. ${ }^{107}$ The Sierra Leonean law demonstrates that it is possible for states to tailor their institutional arrangements to match their particular circumstances.

\subsubsection{Registration and licensing}

Registration and licensing are perhaps the most effective ways of monitoring PMSCs activities within the domestic setting. A licensing and registration regime must enable the enforcement of standards. It should therefore be proactive rather than reactive. One aspect of PMSC operations that such a regime would eliminate is opaqueness and secrecy. Currently, information about their operations, personnel

105 Other bodies that the Act establishes are the National Security Council (NSC) (chaired by the President), Sierra Leone Police (SLP), and the Republic of Sierra Leone Armed Force (RSLAF). See Conteh "Security Sector Reform in Sierra Leone" 9.

106 See Juma 2011 Law Democracy \& Development 202.

107 The SOP sets out guidelines for the issuance of licences, which include minimum wage requirements for personnel, the ownership of sufficient and up-to-date equipment, the training of personnel in international humanitarian law, human and civil rights, and gender-based violence (SOP 5). It also contains guidelines on complaint procedures, especially those that are labour related. See Juma 2011 Law Democracy \& Development 202. 
welfare or even deaths is very scant. ${ }^{108} \mathrm{~A}$ transparent licensing system would lessen the secrecy about their affairs, and at a very practical level, prohibit PMSCs that are not registered and accredited through a public process from operating in or from South Africa. Before registration the company might be required to fulfil a set of criteria based on standards established by the law. By registering the company would be submitting itself to a regulatory regime with constant checks on its operations. Registered companies would then be required to regularly supply information about their operations, including the expertise of their personnel and the training they perform on issues related to human rights and international humanitarian law, and would be required to submit to regional auditing. The legislation must ensure that there will be consequences for non-compliance. A wide range of sanctions could be considered, including blacklisting and deregistration, all of which would affect their business. PMSCs will pay attention to the national regulatory framework only if it affects their marketability.

In designing the registration and licensing framework the new law must take into account international imperatives that are likely to impact on the domestic law. For example, the licensing regime established by the Draft Convention extends beyond the mere authorisation of PMSCs to do business in the territory of a state party. As noted elsewhere, "the process must ensure that PMSCs record for human rights violations and other violations of international law are examined and that the due diligence standards are met". ${ }^{109}$ In addition, the Draft Convention sets out a broad licensing regime that extend beyond the home state. It requires that home states should establish licensing procedures for PMSCs hoping to export their services abroad. ${ }^{110}$ This requirement is galvanised by article 15 , which enjoin states to ensure that the export of military and security services occurs in compliance with appropriate licensing procedures. The Draft Convention also requires that home as well as host states share information regarding PMSCs. ${ }^{111}$ The proposed law could align itself to these requirements and set the benchmark for cooperation even

108 Percy Regulating the Private Security Industry 21.

109 Juma 2011 Law Democracy \& Development 203.

110 Juma 2011 Law Democracy \& Development 203.

111 Juma 2011 Law Democracy \& Development 203. 
among the SADC states. If the new law could require that PMSCs coming from other countries must give proof of their registration before they can operate in South Africa, and if it also makes allowance for the state to share its registration register with other countries, then the ambit of its regulatory framework could be widened.

\subsubsection{Judicial enforcement}

South Africa is developing a strong culture of constitutional litigation primarily based on the articulation of rights. It is conceivable that a regulatory framework that contains standards framed in the language of rights will be subject to constitutional scrutiny. Thus, it is imperative that the new law adopts a viable framework for corporate activity and human rights. Since PMSCs are basically corporate entities, norms that affect their operations should conform to international standards which, according to a Human Rights Council report prepared by John Ruggie, revolve around three principles: the state's duty to protect citizens against human rights abuse by third parties, the corporate responsibility to respect human rights, and the need for effective access to remedies. ${ }^{112}$ These principles have been discussed exhaustively in many studies and we shall not repeat them here. ${ }^{113}$ However, we wish to highlight the question of access to remedies that we believe is crucial to PMSC regulation. In the first place we believe that the new law should create multiple avenues for seeking redress against violations. There should be a procedure through which the regulatory body discussed above can investigate violations and consider individual complaints. Mechanisms through which members of the public can bring complaints are numerous in the international realm and the drafters of the new law have ample precedents to consider. It might be useful if the proposed law had universal jurisdiction as well, so that no matter where the PMSCs operate, complaints can still be brought against them in South Africa. Similarly, latitude for lodging complaints with other human rights bodies such as the South African Human Rights Commission and the African Commission on Human and Peoples Rights

112 See HRC 2008.

113 These principles are also outlined in ECOSOC 2003. See also Mehra 2009-2010 Pac McGeorge Global Bus \& Dev LJ 329 
should exist. Such a procedure should be accessible, simple and effective, and not overburdened by technicalities and bureaucracy.

These apart, the administrative process should not in any way inhibit the rights of access to court under section 34 of the Constitution. In our view effective judicial enforcement is a prerequisite for any meaningful regulatory regime. Thus, legislation must guarantee access to the court and not merely confine resolution of disputes to the administrative organs. Courts are the ultimate arbiters of disputes. This role should never be sidestepped even when the standards sought to be enforced have international implications. Moreover, domestic judicial mechanisms are crucial for achieving maximum compliance with regulatory standards for PMSCs. Several things work in favour of South Africa in this regard. To mention a few, its judicial structure functions better than can be said of most other African states. Secondly, its constitution lays a firm foundation for the application of international law in domestic courts. Thirdly, it has domesticated a number of international treaties that have a bearing on PMSC activities. For example, it has adopted the Rome Statute of the International Criminal Court into domestic law, thus limiting the scope for PMSC personnel who are suspected of having committed international crimes from operating in the country. ${ }^{114}$

\section{Conclusion}

The failure of South Africa to streamline its private security sector by establishing a tight regulatory framework for PMSCs threatens to have repercussions far beyond its borders. This is poised to change if the policy direction encapsulated in the Defence Review culminates in a normative regime. Broadly speaking, the Defence Review has provided a platform for the debates on South Africa's preparedness to address security threats facing Africa and its commitment to continental security. Specifically, however, it has created a unique opportunity for South Africans to consider establishing an appropriate regulatory framework for private military and security

114 Rome Statute of International Criminal Court Act 27 of 2002. See also Du Plessis 2008 www.iss.co.za. 
companies that operate on or from its soil. And this can be achieved only through legislative intervention. We have suggested that such an intervention must aim at harmonising the domestic framework with international trends whilst being guided by the need to make its approach congruent with South Africa's growing regional and continental responsibilities. Notwithstanding, we are equally conscious of the fact that serial defects in South Africa's security infrastructure cannot be cured by a single legislative feat. There are many other variables that must be considered, and while South Africa struggles to harness all possible strategies for reform of the sector, it could begin by streamlining its approach to privatisation and taking advantage of the PMSC phenomenon. A new normative regime for the regulation of PMSCs that conforms to the standards of international law, human rights and international humanitarian law is probably the best way forward. 


\section{Bibliography}

Abrahams "Contemporary Legal Environment"

Abrahams G "The Contemporary Legal Environment" in Mills G and Stremlau J (eds) The Privatisation of Security in Africa (SAIIA Johannesburg 1999) 81106

Abrahamsen and William 2007 Int'/ Relations

Abrahamsen A and William M "Securing the city: Private security companies and none-state authority in global governance" 2007 Int'/ Relations 237-253

Amann 2005 U Pa L Rev

Amann D "Abu Ghraib" 2005 U Pa L Rev 2085-2141

Barker 2005 Int'l Affairs

Barker ] "The new South African foreign policy: Principle and practice" 2005 Int'l Affairs 1079-1096

Barlow Executive Outcomes

Barlow E Executive Outcomes: Against Al/ Odds (Galago Alberton 2008)

Bosch and Maritz 2011 PELJ

Bosch S and Maritz M "South African private security contractors active in armed conflict: Citizenship, prosecution and the right to work" 2011 14(7) PELJ 71-125

Brooks 2007 JIPO

Brooks D "In Search of Adequate Legal and Regulatory Frameworks" 2007 2(5) JIPO 4-14 
Bryton $2002 \mathrm{~J}$ Int Aff

Bryton $S$ "Outsourcing war: mercenaries and the privatization of peacekeeping" 2002 J Int Aff 303-329

Cashore, Auld and Newsom Governing Through Markets

Cashore BW, Auld G and Newsom D Governing Through Markets: Forest Certification and the Emergence of Non-state Authority (Yale University Press New Haven 2004)

Cilliers and Cornwell 1999 ASR

Cilliers $\mathrm{J}$ and Cornwell R "Mercenaries and the Privatisation of Security in Africa" 1999 8(2) ASR 31-42

Cockayne 2009 JCSL

Cockayne J "Regulating private military and security companies: The content, negotiation, weakness and promise of the Montreux Document" 2009 JCSL 401-428

Cockayne et al Beyond Market Forces

Cockynae J et al Beyond Market Force: Regulating the Global Security Industry (Lynne Rienner Boulder, Col. 2010)

Conteh "Security Sector Reform in Sierra Leone"

Conteh K "Security Sector Reform in Sierra Leone and the Role of the Office of the National Security" in Jackson P and Albrecht P (eds) Security Sector Reform in Sierra Leone 1997-2007: Views From the Frontline (DCAF Geneva 2008) $177-189$

Davidson 2000 Pub Cont $L$

Davidson $M$ "Ruck up: An introduction to the legal issues associated with civilian contractors on the battlefield" 2000 Pub Cont LJ 233-261 
Desai 2005 USFL ReV

Desai D "Have your Cake and Eat it Too: A Proposal for Layered Approach to Regulating Private Military Companies" 2005 USFL Rev 825-871

Ebrahim 2010 BU Int'/ $L$

Ebrahim A "Going to war with an army you can afford: The United States, international law and private military industry" 2010 BU Int'/ LJ 181-218

Fallah 2006 IRRC

Fallah K "Corporate Actors: The Legal Status of mercenaries in Armed Conflict" 2006 IRRC 599-611

Franklin 2008 Transnat'/ L \& Contemp Probs

Franklin S "South African and international attempts to regulate mercenaries and private military companies" 2008 Transnat'l L \& Contemp Probs 239-264

Geldenhuys 1982 Politikon

Geldenhuys D "The destabilisation controversy: an analysis of a high-risk foreign policy option for South Africa" 1982 9(2) Politikon 16-31

Gichanga Fusing Privatisation

Gichanga M Fusing Privatisation of Security with Peace and Security Initiatives (Institute for Security Studies Pretoria 2010)

Gillard 2006 IRRC

Gillard E "Business Goes to War: Private Military/Security Companies and International Humanitarian Law" 2006 IRRC 525-572

Gumedze 2007 ASR

Gumedze $S$ "Towards the review of the OAU/African Union Convention on the Elimination of Mercenarism" 2007 16(4) ASR 22-33 
Gumedze Addressing the Use of Private Security

Gumedze S Addressing the Use of Private Security and Military Companies at the International Level (Institute for Security Studies Pretoria 2009)

Gruenbaum 2010 Round Table

Gruenbaum O "Commonwealth News Update" 2010 Round Table 585-600

Hanlon 1987 Third World Quarterly

Hanlon J "Post-apartheid South Africa and its neighbours" 1987 Third World Quarterly 437-450

Holmqvist Private Security Companies

Holmqvist C Private Security Companies: The Case for Regulation (SIPRI Stockholm 2005)

Hoppe 2008 EJIL

Hoppe C "Passing the buck: State responsibility for private military companies" 2008 EJIL 989-1014

Howe 1998 J Mod Afr Stud

Howe $\mathrm{H}$ "Private security forces and African stability: The case of Executive Outcomes" 1998 J Mod Afr Stud 307-331

Hurst 2010 S Cal L Rev

Hurst $S$ "Trade in force: The need for effective regulation of private military and security companies" 2010-2011 S Cal L Rev 447-487

Jackson 2007 J Nat'l Ass'n Admin L Judiciary

Jackson $\mathrm{K}$ "Not quite a contractor, not quite a soldier: How five words could subject civilian contractors in Iraq and Afghanistan to military jurisdiction" 2007 J Nat'l Ass'n Admin L Judiciary 255-290 
Juma "Mercenarism"

Juma L "Mercenarism: Looking beyond the Current International and Regional Normative Regimes" in Gumedze S (ed) Elimination of Mercenarism in Africa: A Need for a New Continental Approach (Institute for Security Studies Pretoria 2008) $197-227$

Juma 2011 Law Democracy \& Development

Juma L "Privatisation, Human Rights and Security: Reflections on the Draft International Convention on Regulation, Oversight and Monitoring of Private Military and Security Companies" 2011 Law Democracy \& Development 182214

Juma 2011 Obiter

Juma L "Going against the tide: Seeking regulation for private military/security companies in a globalized world" 2011 Obiter 63-82

Kagwanja 2006 JCAS

Kagwanja P "Power and peace: South Africa and the refurbishing of Africa's multilateral capacity for peace making" 2006 JCAS 159-184

Kinsey Corporate Soldiers

Kinsey C Corporate Soldiers and International Society: The Rise of Private Military Companies (Routledge Oxford 2006)

Krahmann 2011 Millenn J Int Stud

Krahmann E "From 'mercenaries' to private security contractors': The (re)construction of armed security providers in international legal discourse" 2011 Millenn J Int Stud 343-363

Lock "Africa, Military Downsizing"

Lock P "Africa, Military Downsizing and the Growth in the Private Security Industry" in Cilliers $\mathrm{J}$ and Mason $\mathrm{P}$ (eds) Peace Profit or Plunder? The 
Privatization of Security in War-torn African Societies (Institute for Security Studies Pretoria 1999) 11-36

McIntyre 2004 ASR

McIntyre A "Private military firms in Africa: Rogue or regulated" 2004 ASR 101-103

Mehra 2009-2010 Pac McGeorge Global Bus \& Dev LJ

Mehra A "Bridging accountability gaps: The proliferation of private military and security companies and ensuring accountability for human rights violations" 2009-2010 22 Pac McGeorge Global Bus \& Dev LJ323-332

Mesner "Working Towards Effective Legislation"

Mesner J "Working Towards Effective Legislation and Regulatory Solutions for Private Security Industry in Africa" in Gumedze $\mathrm{S}$ (ed) Elimination of Mercenarism in Africa: A Need for Continental Approach (Institute for Security Studies Pretoria 2008) 145-178

Nevers $2010 \mathrm{~J}$ Pub Pol'y

Nevers R "The effectiveness of self-regulation by private military and security industry" $2010 \mathrm{~J}$ Pub Pol'y 219-240

Pattinson 2010 Int'l Theory

Pattinson J "Outsourcing responsibility to protect: humanitarian intervention and private military and security companies" 2010 Int'/ Theory 1-31

Percy Regulating the Private Security Industry

Percy S Regulating the Private Security Industry (Routledge Oxford 2006)

Percy Mercenaries

Percy S Mercenaries: The History of a Norm in International Relations (Oxford University Press New York 2007) 
Prado 2008 JC \& SL

Prado J "Private military and security companies and the UN Working Group on the Use of Mercenaries" 2008 JC \& SL 429-450

Prado 2011 BJWA

Prado J "Impact on human rights of a new non-state actor: Private military and security companies" 2011 BJWA 151-170

Prado 2012 Criminal Justice Ethics

Prado J "A UN Convention to regulate PMSCs?" 2012 Criminal Justice Ethics 262-286

Prakash 1999 Business Strategy and the Environment

Prakash A "A new institutional perspective on ISO 14000 and responsible care" 1999 Business Strategy and the Environment 322-335

Roux "Revision of the South African Defence Review"

Roux $L$ "The Revision of the South African Defence Review and International Trends in Force Design: Implications for the South African Army" in Le Roux L (ed) South African Army Vision 2020: Security Challenges Shaping the Future South African Army (Institute for Security Studies Pretoria 2007) 269-286

Salzman 2008 NYUJ Int'I L \& Pol

Salzman Z "Private military contractors and the taint of mercenary reputation" 2008 NYUJ Int'I L \& Pol 853-892

Schmitt 2005 Chi J Int'/ L

Schmitt $M$ "Humanitarin law and direct participation in hostilities by private contractors or civilian employees" 2005 Chi J Int'l L 511-546 
Shearer Private Armies

Shearer D Private Armies and Military Intervention (Oxford University Press New York 1998)

Singer Corporate Warrior

Singer P Corporate Warrior: The Rise of Private Military Industry and Its Ramifications for International Security (Cornel University Press New York 2003)

Spearin 2011 Int'l Peacekeeping

Spearin C "UN Peacekeeping and the international private military and security industry" 2011 Int'l Peacekeeping 196-209

Spearin 2012 JICJ

Spearin C "Private military and security companies v. international naval endeavours v. Somali pirates: A security studies perspective" 2012 JICJ 823837

Steinhoff "What are Mercenaries? "

Steinhoff U "What are Mercenaries?" in Alexandria A et al (eds) Private Military and Security Companies: Ethics Policies and Civil Military Relations (Routledge New York 2008) 19-29

Stürchler 2008 JIPO

Stürchler N "The Swiss Initiative Comes Alive" 2008 4(3) JIPO9-12

Taljaard "Private and Public Security"

Taljaard R "Private and Public Security in South Africa" in Gumedze S (ed) Private Security Sector in Africa (Institute for Security Studies Pretoria 2008) $69-98$ 
White 2011 Hum Rts Rev

White $\mathrm{N}$ "The privatisation of military and security functions and human rights: Comments on the UN Working Group's Draft Convention" 2011 Hum Rts Rev 133-151

Zarate 1998 Stan J Int'/ L

Zarate J "The Emergence of the New Dog of War: Private International Security Companies, International Law and the New World Order" 1998 Stan J Int'l L 75-162

\section{Register of legislation}

Constitution of the Republic of South Africa, 1996

Regulation of Foreign Military Assistance Act 15 of 1998

National Conventional Arms Control Act 41 of 2002

Prohibition of Mercenary Activities and Prohibition and Regulation of Certain Activities in Areas of Armed Conflict Act 27 of 2006

Rome Statute of International Criminal Court Act 27 of 2002

\section{Register of policy documents}

White Paper on National Defence for the Republic of South Africa (1996)

White Paper on South Africa Defence Related Industries (1999)

\section{Register of treaties}

OAU Convention for the Elimination of Mercenaries in Africa (1972)

International Convention Against the Recruitment, Use, Financing and Training of Mercenaries (1989) (UN Mercenary Convention)

Montreux Document on Pertinent International Legal Obligations and Good Practices for States Related to Operations of Private Military and Security Companies 
During Armed Conflict, Annex, addressed to the Secretary General (2008) (Montreux Document)

Protocol Additional to the Geneva Conventions of 12 Aug 1949 and Relating to the Protection of the Victims of International Armed Conflicts (1979) (Additional Protocol ()

\section{Register of UN reports}

ECOSOC 2003

UN Economic and Social Council Norms and Responsibilities of Transnational Corporations and the Business Enterprise with Regards to Human Rights UN Doc E/CN.4/Sub.2/2003/12/Rev.2 (2003)

HRC 2007

Report of the Working Group on the Use of Mercenaries as a Means of Violating Human Rights and Impeding the Exercise of the Right of Peoples to Self-Determination to the 4th Session of Human Rights Council A/HRC/4/42 (2007)

HRC 2008

Protect, Respect and Remedy: A Framework for Business and Human Rights UN Doc A/HRC/8/5 (2008)

HRC Res 2005/2

The Use of Mercenaries as a Means of Violating Human Rights and Impeding the Exercise of Rights of Peoples to Self-determination E/CN.4/2005/RES/ 2005/2 (2005)

UNDP 1999

United Nations Development Programme Human Development Report (1999) 
UN GA Res 2625

Implementation of the Declaration on the Granting of Independence to Colonial Countries and Peoples UNGA Res 2465, 23UN GAOR Supp (No 18) at 4 UN Doc A/1218 (1968)

\section{Register of internet sources}

Ahmadou and Gumedze 2008 www.iss.co.za

Ahmadou N and Gumedze S 2008 Seminar Report on Prohibition of Mercenary Activities and Prohibition and Regulation of Certain Activities in Areas of Armed Conflict Act 2006 www.iss.co.za/uploads/RPSSREPFIN.PDF [date of use 10 Mar 2013]

BAPSC 2008 www.org.uk

BAPSC 2008 Charter www.org.uk/key_documents-charter.asp [date of use 24 Sep 2008]

BBC 2004 news.bbc.co.uk

BBC News 2004 Mercenaries Face Zimbabwe Court news.bbc.co.uk/ 2/hi/africa/3500132.stm [date of use 7 Feb 2013]

BBC 2010 news.bbc.co.uk

BBC News 2010 Henry Okah Charged in South Africa over Nigeria Bombs news.bbc.co.uk/news/world-africa-11466445 [date of use 10 Feb 2013]

BBC 2013 news.bbc.co.uk

BBC News 2013 Henry Okah: South African Court Convicts Nigeria Rebel news.bbc.co.uk/news/world-africa-21119470 [date of use 7 Feb 2013]

Clarno and Vally 2005 www.corpwatch.org

Clarno A and S Vally 'Iraq: The South African connection' Corp Watch 6 March 2005 www.corpwatch.org/article.php?id=12061 [date of use 15 Mar 2013] 
CNN 2013 edition.cnn.com

CNN 2013 South African Police Seize Alleged Coup Plotters edition.cnn.com/2013/02/06/world/africa/south-africa-congo-arrests/ index.html accessed on 07/02/2013 [date of use 6 Feb 2013]

Department of Defence 2012 www.info.gov.za

Department of Defence 2012 South African Defence Review (Draft Document for Public Engagement) www.info.gov.za/view/DownloadFileAction?id= 163572 [date of use 15 Mar 2013]

Du Plessis 2008 www.iss.co.za

Du Plessis M 2008 South Africa's International Criminal Court Act: Countering Genocide, War Crimes and Crimes against Humanity, Institute of Security Studies, Paper No. 172 www.iss.co.za/uploads/PAPER172.PDF [date of use 2 Feb 2013]

ICRC 2009 www.icrc.org

ICRC 2009 ICRC's Interpretive Guidance on the Notion of Direct Participation in Hostilities under International Humanitarian Law www.icrc.org/eng/ resources/documents/article/review/review-872-p991.htm [date of use 20 Nov 2012]

Jobson 2012 www.guardian.co.uk

Jobson A 'African Union chooses first female leader' The Guardian 16 July 2012 www.guardian.co.uk/world/2012/jul/16/african-union-first-female-leader [date of use 20 Nov 2012]

Raghavan and White 2007 www.washingtonpost.com

Raghavan S and White J 'Blackwater Guards Fired at Fleeing Cars, Soldiers Say' Washington Post 12 October 2007 www.washingtonpost.com/wpdyn/content/article/2007/10/11/AR2007101101030.html [date of use 20 Nov 2012] 
SABC 2013 www.sabc.co.za

SABC 2013 DRC Awaits SA Brief on Alleged Coup www.sabc.co.za/news/a/ a91f2d004e74f94c9908fb7da4cd6ad7/DRC-awaits-SA-brief-on-alleged-coup20130602 [date of use 7 Feb 2013]

Staff Reporter 2013 mg.co.za

Staff Reporter 'Seven arrested for Mangaung bomb plot' Mail \& Guardian 17 December 2012 hmg.co.za/article/2012-12-17-seven-arrested-for-right-wingbomb-plot accessed on 07/02/2013 [date of use 7 Feb 2013]

Tempest and Jeffrey 2004 www.guardian.co.uk

Tempest and S Jeffrey 'Mark Thatcher denies coup charges' The Guardian 25 August 2004 www.guardian.co.uk/world/2004/aug/25/southafrica.politics [date of use 10 Mar 2013]

UN 2009 mgimo.ru

United Nations 2009 Draft Convention on the Regulation, Oversight and Monitoring of Military and Security Companies mgimo.ru/files/121626/ draft.pdf [date of use 7 Feb 2013]

UN OHCHR Date Unknown www.ohchr.or

United Nations Office of the High Commission for Human Rights Date Unknown Working Group on the Use of Mercenaries as a Means of Violating Human Rights and Impeding the Exercise of the Right of Peoples to Selfdetermination www.ohchr.org/EN/Issues/Mercenaries/WGMercenaries/Pages/ WGMercenariesIndex.aspx [date of use 2 Mar 2013] 


\section{List of abbreviations}

ASR

BAPSC

BJWA

BU Int'I LJ

Chi J Int'l L

ECOSOC

EJIL

HRC

Hum Rts Rev

ICRC

Int'| Affairs

Int'l Peacekeeping

Int'I Relations

Int'l Theory

IPOA

IRRC

J Int Aff

J Mod Afr Stud

J Nat'l Ass'n

Admin L Judiciary

J Pub Pol'y

JC \& SL

JCAS

JIC]

JIPO

JCSL

Millenn J Int Stud

NCACC

NYUJ Int'I L \& Pol
African Security Review

British Association of Private Security Companies

Brown Journal of World Affairs

Boston University International Law Journal

Chicago Journal of International Law

UN Economic and Social Council

European Journal of International Law

United Nations Human Rights Council

Human Rights Review

International Committee of the Red Cross

International Affairs

International Peacekeeping

International Relations

International Theory

International Peace Operations

International Review of the Red Cross

Journal of International Affairs

Journal of Modern African Studies

Journal of the National Association of Administrative Law Judiciary

Journal of Public Policy

Journal of Conflict and Security Law

Journal of Contemporary African Studies

Journal of International Criminal Justice

Journal of International Peace Operations

Journal of Conflict and Security Law

Millennium: Journal of International Studies

National Conventional Arms Control Committee

New York University Journal of International Law and 


\section{Policy}

$\mathrm{OHCHR}$

United Nations Office of the High Commission for Human Rights

Pac McGeorge

Pacific McGeorge Global Business \& Development Law

Global Bus \& Dev LJ

PASA

PEL]

PMSCS

PSCAI

RFMA

Pub Cont LJ

SADF

S Cal L Rev

Stan J Int'I L

Transnat'I L \&

Contemp Probs

U Pa L Rev

UN

UNDP

USFL Rev
Journal

Pan African Security Association

Potchefstroom Electronic Law Journal

Private military and security companies

Private Security Company Association of Iraq

Regulation of Foreign Military Assistance Act

Public Contract Law Journal

South African Defence Forces

Southern California Law Review

Stanford Journal of International Law

Transnational Law and Contemporary Problems

University of Pennsylvania Law Review

United Nations

United Nations Development Programme

University of San Francisco Law Review 